\title{
Emprenye ve Üst yüzey İşlemi Uygulanmış Ceviz Ağaç Malzemenin Yanma Özelliklerinin Belirlenmesi
}

\author{
Cemal ÖZCAN ${ }^{1 *}$ \\ ${ }^{1}$ Karabük Üniversitesi, Safranbolu Fethi Toker Güzel Sanatlar ve Tasarım Fakültesi, Endüstri Ürünleri Tasarımı \\ Bölümü,78600, KARABÜK
}

\section{Öz}

Bu çalışmada, farklı kimyasallarla emprenye edilen ceviz (Juglans regia L.) ağaç malzemede yangın geciktirici üst yüzey işlemlerinin yanma direncine etkileri incelenmiştir. $\mathrm{Bu}$ amaçla emprenye maddesi olarak borik asit, boraks, sodyum silikat, diamonyum fosfat, amonyum sülfat ve çinko klorür kullanılmıştır. Üst yüzey malzemesi olarak ise yangın geciktirici boya ve nano özellikli yangın geciktirici vernik kullanılmıştır. Yanma deneyleri, ASTM-E 69 standartlarına göre geliştirilen bilgisayar kontrollü ağaç malzeme yanma düzeneğinde gerçekleştirilmiştir. Baca gazı analizi Testo $350 \mathrm{M} / \mathrm{Xl}$ gaz analiz cihazıyla gerçekleştirilmiştir. Bu sayede karbon monoksit $(\mathrm{CO})$, azot oksit (NO), oksijen $\left(\mathrm{O}_{2}\right)$ ve baca sıcaklığı değerleri elde edilmiştir. Sonuç olarak, ceviz ağaç malzemeye yangın geciktirici boya ile üst yüzey işlemi uygulamanın, kullanılan tüm emprenye maddelerinden ağırlık kaybını azaltmada daha etkili olduğu gözlemlenmiştir. Bununla birlikte, nano özellikli yangın geciktirici vernik ile üst yüzey işlemi uygulamanın boraks, borik asit, sodyum silikat ve diamonyum fosfat ile emprenye etmekten daha az ağırlık kaybına yol açtığı gözlemlenmiştir.

Anahtar Kelimeler: Ağaç malzeme, yanma, yangın geciktirici, ceviz, üst yüzey

\section{Determination of Combustion Properties of Impregnated and Finished Walnut Wood}

\begin{abstract}
In this study, the effects of the fire retardant finishing processes of walnut (Juglans regia L.) impregnated with different chemicals on the combustion resistance were examined. For this purpose, boric acid, borax, sodium silicate, diammonium phosphate, ammonium sulfate and zinc chloride were used as impregnation material. Fire retardant paint and nano-enabled fire-retardant varnish were used as the finishing material. Combustion tests were carried out with computer-controlled wood material combustion apparatus developed according to ASTM-E 69 standard. Flue gas analysis was performed with the Testo 350M / Xl gas analyzer. In this way, carbon monoxide $(\mathrm{CO})$, nitrogen oxide $(\mathrm{NO})$, oxygen $\left(\mathrm{O}_{2}\right)$ and flue temperature values were obtained. Consequently, it has been observed that finishing of Walnut wood with fire-retardant paint is more effective than impregnation of it with all the impregnation materials used in reducing weight loss. However, it has been observed that the application of nano-type fire retardant varnish results in less weight loss than impregnation with borax, boric acid, sodium silicate and diammonium phosphate.
\end{abstract}

Keywords: Wood material, combustion, fire retardant, walnut, Finishing.

\footnotetext{
*Sorumlu Yazar (Corresponding Author):

Cemal ÖZCAN (Dr.); Karabük Üniversitesi, Safranbolu FTGST Fakültesi, Endüstri 


\section{Giriş}

Öncelikle ısınma, barınma ve av aletleri olarak kullanılan ağaç malzeme günümüzde hemen hemen her yerde kullanılmaktadır. İç ve dış dekorasyonda, ulaşım araçlarında, inşaat sektöründe ve el aletlerinde çeşitli sayıda üretimi yapılıp insanların kullanım alanlarında kendisine yer bulmuştur. Dünyada hızla artan nüfus sebebi ile daha değerli olmuştur. Bu sebeple kullanım alanları daha verimli yönlere çevrilmiştir (Bozkurt ve Göker,1981; Bozkurt ve Erdin, 1997; Özcan, 2007; Ayrılmış, 2006). Ağaç malzeme birçok üstün özelliğine rağmen yanmaya karşı olan direncinin düşük olması önemli dezavantajlarından biridir. Ağaç malzeme ısıya maruz kaldığında tutuşabilir ve yanıcı sıvılar / gazlar salarak yanar. Tutuşmayı azaltmak için ağaç malzeme yangın geciktiricilerle muamele edilir. Bu tür yangın geciktirici uygulamalar ağaç malzemenin yüzeyindeki alev yayılma ve 1sı miktarı oranlarını ciddi bir şekilde azaltır (Russell vd., 2004; LeVan ve Winandy 1990; Kordina ve Meyer-Ottens, 1977; Jinxue vd., 2010; Rowell, 2013). Ağaç malzemenin alevlenme, tutuşma ve yanmaya karşı korunmasında kullanılan kimyasal maddeler inorganik maddeler (alkali tuzlar, amonyum tuzları, bazı metal bileşikler vb.) ve organik maddeler (reçineler ve polimerler, reaktif bileşikler) olmak üzere iki gruba ayrılırlar (Yalınkılıç, 1993; Goldstein, 1973). Günümüzde bor, amonyum, fosfor ve azot bileşikleri bununla birlikte yangın geciktirici üst yüzey malzemeleri odun ve odun kompozitlerini yanmaya karşı korumada sıklıkla kullanılmaktadır (Gao vd., 2006; Ibach, 2013; Özdemir vd., 2017; Jiang vd., 2015; Lee vd., 2004; Keskin vd., 2013; Yapıc1 vd., 2011; Yasar ve Atar, 2018; Budakçı vd., 2016).

Bu çalışmada, yanma direncine ayrı ayrı olumlu etkileri olan emprenye maddeleri ve yangın geciktirici özellikli üst yüzey işlemlerinin birlikte kullanımının sonuçları incelenmiştir. Bu amaçla ceviz ağaç malzeme üzerine farklı emprenye maddeleri ve yangın geciktirici özellikli üst yüzey malzemeleri uygulanarak yanmada ağırlık kaybına etkileri ve baca gazı analizi sonuçları araştırılmıştır.

\section{Materyal ve Metot}

\subsection{Ağaç Malzeme}

Deneylerde kullanılan Ceviz (Juglans regia L.) ağaç malzeme, Karabük ilindeki orman ürünleri tedarikçilerinden rastgele seçim yöntemi ile temin edilmiştir. Ağaç malzemeler hava kurusu halini alıncaya kadar teknik kurutma işlemine tabi tutulmuştur. Ağaç malzemeler Karabük Üniversitesi Safranbolu meslek yüksekokulu atölyesinde istenilen boyutlara getirilmiştir.

\subsection{Emprenye Maddeleri}

Deney örneklerin emprenye işlemlerinde borik asit, boraks, sodyum silikat, diamonyum fosfat, amonyum sülfat ve çinko klorür kimyasalları kullanılmıştır. Çalışma da kullanılan emprenye maddelerinin çözelti, $\mathrm{Ph}$ ve yoğunluk değerleri Tablo.1 'de verilmiştir.

Tablo 1. Kullanılan emprenye maddelerinin çözelti, Ph ve yoğunluk değerleri.

\begin{tabular}{|c|c|c|c|c|c|c|c|}
\hline \multirow[t]{2}{*}{$\begin{array}{l}\text { Emprenye } \\
\text { Kimyasalları }\end{array}$} & \multirow{2}{*}{$\begin{array}{l}\text { Çözelti } \\
\text { Konsantrasyonu } \\
(\%)\end{array}$} & \multirow[t]{2}{*}{ Çözücü } & \multirow[t]{2}{*}{$\begin{array}{l}\text { Saflık } \\
(\%)\end{array}$} & \multicolumn{2}{|l|}{ pH } & \multicolumn{2}{|c|}{$\begin{array}{l}\text { Yoğunluk } \\
\text { (g/ml) }\end{array}$} \\
\hline & & & & EÖ & ES & EÖ & ES \\
\hline Borik Asit & 5 & $\mathrm{Su}$ bazlı & 98 & 5.2 & 5.2 & 1.02 & 1.02 \\
\hline Boraks & 5 & $\mathrm{Su}$ bazlı & 98 & 9.1 & 9.1 & 1.08 & 1.10 \\
\hline Sodyum silikat & 5 & $\mathrm{Su}$ bazlı & 98 & 11.1 & 11.0 & 0.94 & 0.96 \\
\hline $\begin{array}{l}\text { Diamonyum } \\
\text { Fosfat }\end{array}$ & 5 & $\mathrm{Su}$ bazlı & 97 & 7.8 & 7.8 & 1.07 & 1.09 \\
\hline $\begin{array}{l}\text { Amonyum } \\
\text { Sülfat }\end{array}$ & 5 & $\mathrm{Su}$ bazlı & 97 & 6.2 & 6.1 & 1.05 & 1.06 \\
\hline Çinko Klorür & 5 & $\mathrm{Su}$ bazlı & 99 & 6.0 & 5.9 & 1.07 & 1.07 \\
\hline
\end{tabular}




\section{3. Üst yüzey Malzemeleri}

Yapılan çalışmada üst yüzey malzemesi olarak yangın geciktirici boya ve nano özellikli yangın geciktirici vernik kullanılmıştır. Yangın geciktirici boya; poliüretan esaslı yangın geciktirici özelliğine sahip bir boyadır. Bu boya yanıcı bir maddeyi, 1sıdan izole etmeye yarayan ve 1sıtıldıklarında köpüksü bir yapı oluşturan intumesan tarz bir malzemedir. Nano vernik; poliüretan esaslı yangın geciktirici özelliğine sahip bir verniktir. Ahşabın hemen tutuşmasını engelleyerek yangının ilerleme hızını indirgeyen ve toksik duman oluşturmayan yangın geciktirici vernik sistemidir. Boya ve vernik uygulanırken üretici firmaların önerileri dikkate alınmıştır (Üretici Firma 1-2, 2018).

\subsection{Deney Örneklerinin Hazırlanması}

Deney örnekleri, ASTM-E-69 (2007)'a göre 9,5x19x1016mm $\pm 0,8 \mathrm{~mm}$ boyutlarında düzgün olacak şekilde kesilmiştir. Ceviz ağaç malzemeden emprenyeli, üst yüzey işlemli ve kontrol olarak da 10 'ar adet deney numunesi hazırlanmıştır. Buna göre; $7 * 3 * 10=210$ adet ceviz deney örneği hazırlanmıştır. ASTM-E-69'a göre yanma testi yapılacak malzemelerin rutubeti tam kuru ağırlığına oranla $\% 10 \pm 3$ olması gerekmektedir. Bunun için örnekler klimatize dolabında $20^{\circ} \mathrm{C} \pm 2^{\circ} \mathrm{C}$ ve $\% 65 \pm 5$ bağıl nemde $\% 12$ rutubet dengesi oluşuncaya kadar bekletilmiştir.

\subsection{Yoğunluk}

Deney numunelerinin rutubetleri TS 2471(1976) yoğunlukları TS 2472(1976) belirtilen esaslarına uygun olarak belirlenmiştir. Deney numuneleri $20 \pm 2{ }^{\circ} \mathrm{C}$ sıcaklık ve $\% 65 \pm 3$ bağıl nem şartlarındaki iklimlendirme dolabında bekletilmiştir. Değiş̧mez ağırlığa ve boyutsal stabiliteye ulaştıktan sonra $0.001 \mathrm{~g}$ duyarlıklı hassas terazide tartılmış olup boyutları da $\pm 0.01 \mathrm{~mm}$ duyarlıklı kumpas ile ölçülerek hacimleri belirlenmiştir. Daha sonra hava kurusu haldeki ağırlık $\left(\mathrm{M}_{12}\right)$ ve hacim $\left(\mathrm{V}_{12}\right)$ değerine göre hava kurusu yoğunluk $\left(\delta_{12}\right)$;

$$
\delta_{12}=\mathrm{M}_{12} / \mathrm{V}_{12} \mathrm{~g} / \mathrm{cm}^{3}
$$

eşitliğinden hesaplanmıştır.

\subsection{Emprenye İşlemi}

Ağaç malzeme örneklerinin emprenye işleminde; borik asit, boraks, sodyum silikat, diamonyum fosfat, amonyum sülfat ve çinko klorür olmak üzere altı çeşit kimyasal madde kullanılmıştır. Hazırlanan deney örnekleri uzun süreli daldırma yöntemi (72 saat) ile emprenye edilmiştir. Boyutlandırılan ve kurutulan deney örnekleri camdan yapılmış ve iki ayrı bölmesi bulunan emprenye havuzunda, ASTM D 1413-99 (1999) esaslarına uygun olarak, her bölmedeki kimyasal madde çözeltileri içerisinde bekletilerek emprenye yapılmıştır. Deney örnekleri üst üste istiflenirken kimyasal çözeltinin yüzeylere temasını en iyi şekilde sağlamak amacı ile, örnekler arasına istif çıtaları konularak istif yapılmıştır. Deney örneklerinin çözelti yüzeyine çıkmamaları için de örnekler üzerine ağırlık koyulmuş ve belirlenen konsantrasyondaki çözelti sıvıları, deney örneklerinin yüzeyinin $4-5 \mathrm{~cm}$ üzerinde olacak şekilde havuza doldurulmuştur. Hazırlanan çözeltilerin emprenye öncesinde ve sonrasında $(\mathrm{pH})$ ve yoğunlukları $(\mathrm{g} / \mathrm{mm})$ belirlenmiştir. Deney örnekleri emprenye yapıldıktan sonra emprenye havuzundan çıkartılarak üzerindeki fazla sıvı maddenin atılması amacı ile düzgün olarak istiflenmiştir. Daha sonra iklimlendirme odasında $20^{\circ} \mathrm{C} \pm 2{ }^{\circ} \mathrm{C}$ ve $\% 65 \pm 5$ bağıl nemde değişmez ağırlığa gelinceye kadar bekletilmiştir. Kurutulan örnekler 0,01 hassasiyetteki analitik terazide tartılmıştır. Ağaç malzeme örneklerinin retensiyon miktarları aşağıdaki formüle göre hesaplanmıştır.

$$
R=\frac{M_{12 e s}-M_{12 e \ddot{o}}}{M_{12 e \ddot{e}}} \times 100 \quad \text { eşitliğinden hesaplanmıştır. }
$$

Bu eşitlikte;

$\mathrm{R}=$ Retensiyon

M12eö = Deney numunesinin emprenye öncesi \% 12 rutubetteki ağırlı̆̆

M12es = Deney numunesinin emprenye sonrasındaki \% 12 rutubetteki ağırlığı

\section{7. Üst yüzey İşlemi}

Üst yüzey işlemlerinde üst yüzey malzemesi olarak yangın geciktirici boya ve nano özellikli yangın geciktirici vernik olmak üzere iki çeşit yangın geciktirici özellikte üst yüzey işlem malzemesi uygulanmıştır. Deney örneklerinin üst yüzey işlem uygulamalarında ASTM-D 3023(2011) esasları dikkate alınmıştır. Üst yüzey malzemeleri, üretici firmaların önerileri doğrultusunda emprenyeli ağaç malzeme deney örneklerine rulo ile 
sürülerek uygulanmıştır. Yine üretici firma önerilerine uygun olarak 24 saat beklendikten sonra 180 numara zımpara ile zımparası yapılan örneklere son kat uygulanmış ve \% 12 rutubet için $20 \pm 2^{\circ} \mathrm{C}$ sıcaklık ve $\% 65 \pm 5$ bağıl nem şartlarında üç hafta süreyle kurumaya bırakılmıştır. Deneylerde kullanılan boya ve verniğin uygulama şartlarına gelebilmesi ve istenilen katman kalınlığının elde edilebilmesi için; üretici firmaların aynı ürünleri için önerdikleri tiner, sertleştirici veya seyreltici maddeler ve oranları dikkate alınarak hazırlanmıştır.

\subsection{Yanma Deneyi}

Ağaç malzeme yanma deneyi, ASTM E-69 prensiplerine göre hazırlanmış bilgisayar kontrollü ağaç malzeme yanma düzeneğinde yapılmıştır. Yanma deneyi, dört dakika alev kaynaklı ve altı dakika alev kaynaksız yanma olmak üzere toplam on dakika boyunca devam etmiştir. Sıcaklık değeri düzenenekte bulunan sıcaklık sensörü yardımıyla tespit edilmiştir. Baca gazı analizi Testo 350M/Xl gaz analiz cihazıyla gerçekleştirilmiştir. Bu sayede karbon monoksit $(\mathrm{CO})$, azot oksit $(\mathrm{NO})$, oksijen $\left(\mathrm{O}_{2}\right)$ ve baca sıcaklığı değerleri belirlenmiştir. Şekil 1'de deneylerde kullanılan bilgisayar kontrollü yanma deney düzeneği verilmiştir (Özcan 2011).

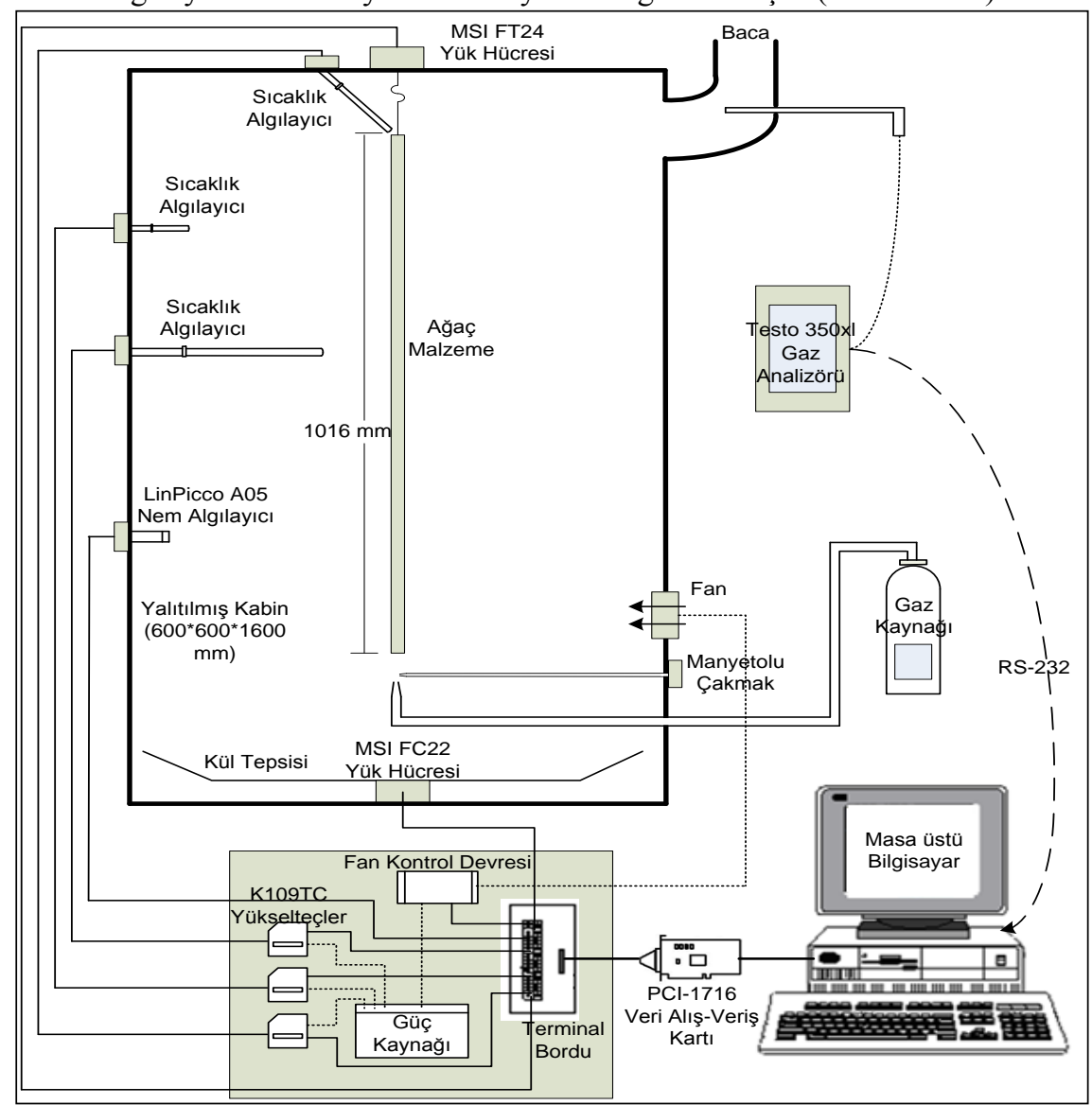

Şekil 1. Bilgisayar kontrollü yanma deney düzeneği (Özcan 2011).

\subsection{Verilerin Değerlendirmesi}

$\mathrm{Bu}$ çalışmada; emprenye maddesi türleri, üst yüzey işlem maddesi türleri, malzemelerin alev kaynaklı - alev kaynaksız ağırlık kaybı ve yanma deneyi süresince oluşan sıcaklık ve baca gazı analizi değerleri incelenmiştir. $\mathrm{Bu}$ verilerin belirlenmesi amacı ile yapılan çalışmadan elde edilen sonuçlara istatistik paket programı kullanılarak çoklu varyans analizi uygulanmıştır. Faktörlerin \%5 hata payı ile karşılıklı etkileşiminin anlamlı çıkması halinde önem derecesini belirtmek için de Duncan testi uygulanmıştır.

\section{Bulgular ve Tartışma}

Ceviz ağaç malzemenin kontrol, yangın geciktirici boya ve nano özellikli yangın geciktirici vernik örneklerinin yanma deneyi sonucunda elde edilen ağırlık kaybı, sıcaklık, O2, CO, NO, baca sıcaklığı değerlerine ait ortalama sonuçları Tablo 2'de, çoklu varyans analiz sonuçları Tablo 3.’de görülmektedir. 
Tablo 2. Yanma deneyi ortalama sonuçları

\begin{tabular}{|c|c|c|c|c|c|c|c|c|}
\hline \multirow[t]{2}{*}{$\begin{array}{l}\text { Üst yüzey } \\
\text { Maddeleri }\end{array}$} & \multirow[t]{2}{*}{ Emprenye Maddesi } & \multicolumn{2}{|c|}{$\begin{array}{c}\text { Ağırlık Kaybı } \\
(\%)\end{array}$} & \multirow[t]{2}{*}{$\begin{array}{l}\text { Sicaklık } \\
\left({ }^{\circ} \mathrm{C}\right)\end{array}$} & \multirow[t]{2}{*}{$\begin{array}{l}\mathrm{O}_{2} \\
(\%)\end{array}$} & \multirow[t]{2}{*}{$\begin{array}{l}\text { CO } \\
(\mathbf{p p m})\end{array}$} & \multirow[t]{2}{*}{$\begin{array}{l}\text { NO } \\
\text { (ppm) }\end{array}$} & \multirow{2}{*}{$\begin{array}{l}\text { Baca } \\
\text { sicaklı̆g } \\
\left({ }^{\circ} \mathbf{C}\right)\end{array}$} \\
\hline & & $\begin{array}{c}8 . \\
\text { ölçüm }\end{array}$ & $\begin{array}{l}20 . \\
\text { ölçüm }\end{array}$ & & & & & \\
\hline \multirow{7}{*}{ Kontrol } & Kontrol & 43,89 & 99,66 & 338,45 & 18,89 & 247,80 & 13,39 & 143,2 \\
\hline & Boraks & 26,42 & 37,04 & 176,25 & 19,39 & 98,10 & 3,56 & 96,71 \\
\hline & Borik Asit & 28,75 & 37,63 & 149,25 & 18,76 & 116,70 & 4,26 & 91,23 \\
\hline & Çinko Klorür & 27,38 & 35,84 & 167,85 & 19,88 & 111,20 & 3,29 & 95,50 \\
\hline & Amonyum Sülfat & 25,16 & 36,23 & 142,10 & 18,98 & 93,50 & 4,03 & 88,15 \\
\hline & Sodyum Silikat & 25,48 & 38,42 & 163,75 & 19,39 & 219,80 & 7,61 & 139,55 \\
\hline & Diamonyum Fosfat & 27,09 & 37,89 & 135,90 & 19,84 & 77,40 & 9,12 & 82,90 \\
\hline Nano & Kontrol & 16,87 & 36,01 & 146,50 & 20,15 & 156,80 & 19,68 & 88,05 \\
\hline özellikli & Boraks & 24,39 & 31,25 & 172,25 & 19,43 & 99,20 & 9,89 & 90,66 \\
\hline yangın & Borik Asit & 23,00 & 33,24 & 145,10 & 18,96 & 103,70 & 10,11 & 89,72 \\
\hline \multirow{4}{*}{$\begin{array}{l}\text { geciktirici } \\
\text { vernik }\end{array}$} & Çinko Klorür & 23,23 & 29,76 & 163,30 & 19,66 & 94,30 & 9,36 & 87,60 \\
\hline & Ámonyum Sülfat & 21,91 & 31,66 & 139,50 & 19,11 & 98,80 & 9,47 & 86,85 \\
\hline & Sodyum Silikat & 21,40 & 33,43 & 125,50 & 20,27 & 134,40 & 16,87 & 75,50 \\
\hline & Diamonyum Fosfat & 25,30 & 34,24 & 135,30 & 20,00 & 94,10 & 9,04 & 82,90 \\
\hline Yangın & Kontrol & 16,18 & 26,38 & 138,45 & 20,27 & 155,60 & 15,52 & 74,65 \\
\hline geciktirici & Boraks & 14,75 & 22,59 & 122,75 & 19,89 & 73,40 & 9,41 & 87,76 \\
\hline \multirow{5}{*}{ boya } & Borik Asit & 15,57 & 22,92 & 122,85 & 19,72 & 78,90 & 9,86 & 84,92 \\
\hline & Çinko Klorür & 14,63 & 22,35 & 160,40 & 20,17 & 89,90 & 8,9 & 83,35 \\
\hline & Amonyum Sülfat & 13,87 & 20,44 & 111,25 & 20,01 & 94,10 & 9,04 & 73,85 \\
\hline & Sodyum Silikat & 16,12 & 26,15 & 162,85 & 19,66 & 179,20 & 14,11 & 90,50 \\
\hline & Diamonyum Fosfat & 16,53 & 26,75 & 144,85 & 19,98 & 159,20 & 15,95 & 83,35 \\
\hline
\end{tabular}

8.ölçüm: Alev kaynaklı yanma sonucu 20.ölçüm :Yanma sonucu

Tablo 2'deki, ağırlık kaybı sonuçlarına göre; alev kaynaklı yanma sonunda en fazla ağırlık kaybı, \%43,89 ile kontrol (emprenye edilmemiş ve üst yüzey işlemi uygulanmamış) örneklerinde, en az ağırlık kayb1 \%13,87 ile amonyum sülfat ile emprenye edilmiş ve yangın geciktirici boya uygulanmış örneklerde tespit edilmiştir. Yanma sonunda ise en fazla ağırlık kaybı \%99,66 ile kontrol örneklerinde, en az ağırlık kaybı \%20,44 ile amonyum sülfat ile emprenye edilmiş ve yangın geciktirici boya uygulanmış örneklerde tespit edilmiştir. Sıcaklık ortalama değerleri incelendiğinde; en yüksek ortalama değer $338,45^{\circ} \mathrm{C}$ ile kontrol (emprenye edilmemiş ve üst yüzey işlemi uygulanmamış) örneklerinde, en düşük ortalama değer ise $111,25^{\circ} \mathrm{C}$ ile amonyum sülfat ile emprenye edilmiş ve yangın geciktirici boya uygulanmış örneklerde gözlemlenmiştir.

Yine verilen tabloda, baca gazı analizi sonuçları incelendiğinde; en yüksek ortalama $\mathrm{O}_{2}$ değerleri \%20,27 ile sodyum silikat ile emprenye edilmiş ve nano özellikli yangın geciktirici vernik uygulanmış örneklerde ve yangın geciktirici boya uygulanmış emprenyesiz örneklerde tespit edilirken, en düşük ortalama $\mathrm{O}_{2}$ değerleri \%18,76 ile borik asit ile emprenye edilmiş üst yüzey işlemi uygulanmamış örneklerde tespit edilmiştir. En yüksek ortalama CO değerleri 247,80 ile kontrol örneklerinde tespit edilirken, en düşük ortalama CO değerleri 73,40 ile boraks ile emprenye edilmiş yangın geciktirici boya uygulanmış örneklerde tespit edilmiştir. En yüksek ortalama NO değerleri 19,68 ile nano özellikli yangın geciktirici vernik uygulanmış emprenyesiz örneklerde tespit edilirken, en düşük ortalama NO değerleri 3,29 ile çinko klorür ile emprenye edilmiş üst yüzey işlemi uygulanmamış örneklerde tespit edilmiştir. Baca sıcaklığı ortalama değerleri incelendiğinde; en yüksek değer $143,20^{\circ} \mathrm{C}$ ile kontrol örneklerinde, en düşük değer ise $73,85^{\circ} \mathrm{C}$ ile amonyum sülfat ile emprenye edilmiş ve yangın geciktirici boya uygulanmış örneklerde gözlemlenmiştir.

Üst yüzey malzemelerine göre ağırlık kaybı değerleri genel olarak karşılaştırıldığında yangın geciktirici boya örnekleri en düşük ağırlık kaybı değerlerini vermiştir. Daha önce yaptığımız çalışmalarda yangın geciktirici boyanın paralel sonuçlar verdiği gözlemlemiştik. (Özcan vd., 2012; 2013; 2018). Emprenye maddelerine göre ağırlık kaybı değerleri genel olarak karşılaştırıldığında çinko klorür ve amonyum sülfat örnekleri en düşük ağırlık kaybı değerlerini vermiştir. Bununla birlikte üst yüzey işlemi uygulanmamış (kontrol) örneklerde de çinko klorür ve amonyum sülfat en düşük ağırlık kaybını vermiştir. Emprenye maddesinin etkisi daha önce yapılan çalışmalara yakın sonuçlar vermiştir (Yapıcı vd., 2011; Kurt ve Uysal 2009). 
Tablo 3. Ceviz ağaç malzeme ağırlık kaybı, sıcaklık, $\mathrm{O}_{2}, \mathrm{CO}$, NO ve baca sıcaklığı ortalama değerlerinin çoklu varyans analiz sonuçları.

\begin{tabular}{|c|c|c|c|c|c|}
\hline $\begin{array}{l}\text { Varyans } \\
\text { Kaynakları }\end{array}$ & Kareler Toplamı & $\begin{array}{l}\text { Serbestlik } \\
\text { Derecesi }\end{array}$ & Ortalama Kareler & F Hesap & $\begin{array}{l}\text { Anlam } \\
\text { Düzeyi }\end{array}$ \\
\hline \multicolumn{6}{|l|}{ Ăğırık kaybı } \\
\hline Düzeltilmiş Model & $147633,686 a$ & 20 & 7381,684 & 58,979 & 0,000 \\
\hline Sabit Terim & 1116638,504 & 1 & 1116638,504 & 8921,780 & 0,000 \\
\hline A & 61992,497 & 2 & 30996,249 & 247,656 & 0,000 \\
\hline B & 28697,882 & 6 & 4782,980 & 38,215 & 0,000 \\
\hline $\mathbf{A} * \mathbf{B}$ & 56943,306 & 12 & 4745,276 & 37,914 & 0,000 \\
\hline \multicolumn{6}{|l|}{ Sicaklık } \\
\hline Düzeltilmiş Model & $206989,912 a$ & 20 & 10349,496 & 1234,848 & 0,000 \\
\hline Sabit Terim & 2537216,038 & 1 & 2537216,038 & 302727,404 & 0,000 \\
\hline A & 28246,473 & 2 & 14123,236 & 1685,111 & 0,000 \\
\hline B & 59910,604 & 6 & 9985,101 & 1191,370 & 0,000 \\
\hline $\mathbf{A} * \mathbf{B}$ & 118832,836 & 12 & 9902,736 & 1181,543 & 0,000 \\
\hline \multicolumn{6}{|l|}{$\mathbf{O}_{2}$} \\
\hline Düzeltilmiş Model & $22,845 \mathrm{a}$ & 20 & 1,142 & 16,672 & 0,000 \\
\hline Sabit Terim & 40495,716 & 1 & 40495,716 & 591055,074 & 0,000 \\
\hline A & 7,472 & 2 & 3,736 & 54,528 & 0,000 \\
\hline B & 7,755 & 6 & 1,292 & 18,865 & 0,000 \\
\hline $\mathbf{A} * \mathbf{B}$ & 7,618 & 12 & ,635 & 9,266 & 0,000 \\
\hline \multicolumn{6}{|l|}{$\mathrm{CO}$} \\
\hline Düzeltilmiş Model & $222960,533 a$ & 20 & 11148,027 & 725,468 & 0,000 \\
\hline Sabit Terim & 1577371,717 & 1 & 1577371,717 & 102648,919 & 0,000 \\
\hline A & 12520,476 & 2 & 6260,238 & 407,391 & 0,000 \\
\hline B & 151803,400 & 6 & 25300,567 & 1646,458 & 0,000 \\
\hline $\mathbf{A} * \mathbf{B}$ & 58636,657 & 12 & 4886,388 & 317,986 & 0,000 \\
\hline \multicolumn{6}{|l|}{ NO } \\
\hline Düzeltilmiş Model & $2005,203 a$ & 20 & 100,260 & 346,276 & 0,000 \\
\hline Sabit Terim & 10710,040 & 1 & 10710,040 & 36990,089 & 0,000 \\
\hline A & 692,691 & 2 & 346,345 & 1196,199 & 0,000 \\
\hline B & 1089,311 & 6 & 181,552 & 627,040 & 0,000 \\
\hline $\mathbf{A} * \mathbf{B}$ & 223,201 & 12 & 18,600 & 64,241 & 0,000 \\
\hline \multicolumn{6}{|l|}{ Baca sıcaklığı } \\
\hline Düzeltilmiş Model & $31441,228 \mathrm{a}$ & 20 & 1572,061 & 172,811 & 0,000 \\
\hline Sabit Terim & 873763,541 & 1 & 873763,541 & 96049,546 & 0,000 \\
\hline A & 8687,702 & 2 & 4343,851 & 477,503 & 0,000 \\
\hline B & 5999,664 & 6 & 999,944 & 109,920 & 0,000 \\
\hline $\mathbf{A} * \mathbf{B}$ & 16753,862 & 12 & 1396,155 & 153,474 & 0,000 \\
\hline
\end{tabular}

Tablo 3'teki, çoklu varyans analiz sonuçlarına göre, üst yüzey işlemi ve emprenye maddesi tek başına ve aynı anda ölçülen \% ağırlık kaybı, sıcaklık, $\mathrm{O}_{2}, \mathrm{CO}$, NO ve baca sıcaklığı ortalama değerleri üzerinde etkileri anlamlı bulunmuştur. Üst yüzey işlemi ve emprenye maddesine bağlı olarak yanma deneyi ortalama değişimlerinin anlam düzeyini belirlemek için yapılan Duncan testi sonuçları Tablo 4 ve 5 'te görülmektedir. 
Tablo 4. Yanma deneyi emprenye ortalama değerlerine ilişkin Duncan testi sonuçları.

\begin{tabular}{|c|c|c|c|c|c|c|c|c|c|c|c|c|}
\hline \multirow[t]{2}{*}{ Varyasyon } & \multicolumn{2}{|c|}{$\begin{array}{l}\text { Ağırlık } \\
\text { Kaybı(\%) }\end{array}$} & \multicolumn{2}{|c|}{ Sicaklık } & \multicolumn{2}{|l|}{$\mathbf{O}_{2}$} & \multicolumn{2}{|l|}{$\mathrm{CO}$} & \multicolumn{2}{|l|}{ NO } & \multicolumn{2}{|c|}{$\begin{array}{l}\text { Baca } \\
\text { Sıcaklığı }\end{array}$} \\
\hline & $\mathbf{X}$ & HG & $\mathbf{X}$ & HG & $\mathbf{X}$ & HG & $\mathbf{X}$ & HG & $\mathbf{X}$ & HG & $\mathbf{X}$ & HG \\
\hline $\mathbf{K}$ & 31,83 & d & 207,80 & f & 19,77 & d & 186,73 & f & 16,20 & e & 102,10 & e \\
\hline BO & 21,48 & abc & 157,08 & d & 19,57 & c & 90,23 & $\mathbf{a}$ & 7,49 & $\mathbf{a}$ & 91,71 & d \\
\hline BA & 21,82 & abc & 139,07 & b & 19,15 & $\mathbf{a}$ & 99,77 & c & 8,08 & b & 88,08 & bc \\
\hline ÇK & 21,10 & $\mathbf{a b}$ & 163,85 & e & 19,90 & d & 98,47 & c & 7,18 & $\mathbf{a}$ & 88,82 & c \\
\hline AS & 19,90 & $\mathbf{a}$ & 139,17 & b & 19,37 & b & 95,47 & b & 7,51 & $\mathbf{a}$ & 85,97 & b \\
\hline SS & 22,11 & bc & 150,70 & c & 19,77 & d & 177,07 & e & 12,86 & d & 101,85 & e \\
\hline DF & 23,18 & c & 130,47 & $\mathbf{a}$ & 19,94 & d & 110,23 & d & 11,37 & c & 80,03 & $\mathbf{a}$ \\
\hline
\end{tabular}

X: ortalama veriler, HG: Homojenlik Grubu, K: Kontrol, BO: Boraks, BA: Borik Asit, ÇK: Çinko Klorür, AS: Amonyum Sülfat, SS: Sodyum Silikat, DF: Diamonyum Fosfat

Tablo 4'e göre, Emprenye türünün ağırlık kaybı ortalama değerlerinin istatistiksel olarak karşılaştırılmasının yapılması sonucu; boraks ve borik asit grupları kendi arasında anlamlı fark görülmemiştir. Bununla birlikte diğer tüm gruplar arasındaki etkileşimlerde anlamlı fark görülmüştür. Sıcaklık ortalama değerlerinin istatistiksel olarak karşılaştırılmasının yapılması sonucu; amonyum sülfat ve borik asit grupları kendi arasında anlamlı fark görülmemiştir ve diğer tüm gruplar arasındaki etkileşimlerde anlamlı fark görülmüştür. $\mathrm{O}_{2}$ ortalama değerlerinin istatistiksel olarak karşılaştırılmasının yapılması sonucu; sodyum silikat, diamonyum fosfat, çinko klorür ve kontrol grupları kendi arasında anlamlı fark görülmemiştir ve amonyum sülfat, boraks ve borik asit grupları arasında anlamlı fark görülmüştür. CO ortalama değerlerinin istatistiksel olarak karşılaş̧ırılmasının yapılması sonucu; çinko klorür ve borik asit grupları kendi arasında anlamlı fark görülmemiştir. Bununla birlikte diğer tüm gruplar arasındaki etkileşimlerde anlamlı fark görülmüş̧ür. NO ortalama değerlerinin istatistiksel olarak karşılaştırılmasının yapılması sonucu; amonyum sülfat, çinko klorür ve boraks grupları kendi arasında anlamlı fark görülmemiştir. Bununla birlikte diğer tüm gruplar arasındaki etkileşimlerde anlamlı fark görülmüştür. Baca sıcaklığı ortalama değerlerinin istatistiksel olarak karş̧laştırılmasının yapılması sonucu; sodyum silikat ve kontrol grupları kendi arasında anlamlı fark görülmemiştir. Bununla birlikte diğer tüm gruplar arasındaki etkileşimlerde anlamlı fark görülmüştür.

Tablo 5. Yanma deneyi üst yüzey ortalama değerlerine ilişkin Duncan testi sonuçları.

\begin{tabular}{|c|c|c|c|c|c|c|c|c|c|c|c|c|}
\hline \multirow[t]{2}{*}{ Varyasyon } & \multicolumn{2}{|c|}{$\begin{array}{l}\text { Ağırlık } \\
\text { Kaybı(\%) }\end{array}$} & \multicolumn{2}{|l|}{ Sicaklık } & \multicolumn{2}{|l|}{$\mathbf{O}_{2}$} & \multicolumn{2}{|l|}{$\mathrm{CO}$} & \multicolumn{2}{|l|}{ NO } & \multicolumn{2}{|c|}{$\begin{array}{l}\text { Baca } \\
\text { Sicaklığı }\end{array}$} \\
\hline & $\mathbf{X}$ & HG & $\mathbf{X}$ & HG & $\mathbf{X}$ & HG & $\mathbf{X}$ & HG & $\mathbf{X}$ & HG & $\mathbf{X}$ & HG \\
\hline Kontrol & 29,99 & c & 178,41 & c & 19,30 & c & 137,47 & c & 6,47 & $\mathbf{a}$ & 104,03 & c \\
\hline $\begin{array}{l}\text { Nano } \\
\text { özellikli } \\
\text { yangın } \\
\text { geciktirici } \\
\text { vernik }\end{array}$ & 22,46 & b & 146,78 & b & 19,65 & b & 111,61 & $\mathbf{a}$ & 12,00 & b & 85,89 & b \\
\hline $\begin{array}{l}\text { Yangın } \\
\text { geciktirici } \\
\text { boya }\end{array}$ & 16,73 & $\mathbf{a}$ & 141,15 & $\mathbf{a}$ & 19,95 & $\mathbf{a}$ & 118,61 & b & 11,83 & b & 83,74 & $\mathbf{a}$ \\
\hline
\end{tabular}

Tablo 5'e göre, üst yüzey işlem türünün ağırlık kaybı, sıcaklık, $\mathrm{O}_{2}, \mathrm{CO}$, baca sıcaklığı ortalama değerlerinin istatistiksel olarak karşılaştırılmasının yapılması sonucu; tüm gruplar arasındaki etkileşimlerde anlamlı fark görülmüştür. NO ortalama değerlerinin istatistiksel olarak karşılaştırılmasının yapılması sonucu; vernik ve boya grupları kendi arasında anlamlı fark görülmemiştir. Bununla birlikte kontrol gruplar arasındaki etkileşimlerde anlamlı fark görülmüştür.

\section{Sonuç ve Öneriler}

Deneysel çalışma sonucunda; 
1. Ceviz ağaç malzemeyi nano özellikli yangın geciktirici vernik ile üst yüzey işlemi uygulamanın; boraks, borik asit, sodyum silikat ve diamonyum fosfat ile emprenye etmekten daha az ağırlık kaybına yol açtığı gözlemlenmiştir.

2. Ceviz ağaç malzemeyi, yangın geciktirici boya ile üst yüzey işlemi uygulamanın; kullanılan tüm emprenye maddelerinden ağırlık kaybını azaltmada daha etkili olduğu gözlemlenmiştir.

3. Yangın geciktirici boya uygulanan kontrol (emprenye uygulanmayan) örnekleri sodyum silikat ve diamonyum fosfat ile emprenye edilen örneklerden daha iyi sonuçlar vermiştir. Bu sonuç yangın geciktirici boya uygulanacak ceviz ağaç malzemeye emprenye uygulamanın gereksiz olduğunu göstermiştir.

4. Üst sıcaklık değerlerinin genel olarak ağırlık kaybı değerlerine paralel sonuçlar verdiği görülmüştür. Ağırlık kaybı değerleri attıkça sıcaklık değerleri de artmıştır.

5. Yangın geciktirici boya ve nano özellikli yangın geciktirici vernik uygulanan örneklerde yanma $\mathrm{CO}$ ve NO salınımın daha yüksek olduğu gözlemlenmiştir.

6. Genellikle elde edilen baca sıcaklık değerleri, üst sıcaklık değerlerine paralel olduğu gözlemlenmiştir.

7. Emprenye uygulanacak ceviz ağaç malzemeyi çinko klorür ve amonyum sülfat ile emprenye edilmesi önerilmektedir.

8. Ceviz ağaç malzemenin üst yüzey işlemlerinde yangın geciktirici boya önerilmektedir.

9. Kullanılan emprenye maddeleri ve üst yüzey malzemeleri ve kullanılan metotların, yanma direncini arttırmada, verimin (fayda-maliyet) araştırılması önerilebilir.

\section{Kaynaklar}

1. ASTM D 1413-99 (1999). Standard test method for wood preservatives by laboratory soil block cultures. American Society for Testing Materials, West Conshohocken.

2. ASTM D 3023 (2011). Standart Practice for Determination of resistance of Factory-Applied Coatings on Wood Products of Stain and Reagents. American Society for Testing Materials, West Conshohocken.

3. ASTM E 69 (2007). Standard test method for combustible properties of treated wood by the fire tube apparatus, American Society for Testing Materials, West Conshohocken.

4. Ayrılmış, N. (2006). Çeşitli Kimyasalların Bazı Ahşap Levha Ürünlerinde Yanma ve Teknolojik Özellikler Üzerine Etkisi, Doktora Tezi, İÜ Fen Bilimleri Enstitüsü, Orman Endüstri Mühendisliği Anabilim Dalı, İstanbul, $400 \mathrm{~s}$.

5. Bozkurt, Y., Göker, Y. (1981). Orman Ürünlerinden Faydalanma, İstanbul Üniversitesi Orman Fakültesi Yayınları, İstanbul, 297s.

6. Bozkurt, A., Erdin, N. (1997). Ağaç Teknolojisi, İstanbul Üniversitesi Orman Fakültesi Yayınları, İstanbul.

7. Budakçı, M., Esen, R., Özcan, C., Korkmaz, M., Pelit, H. (2016). The Effect of Boric Acid Modification on the Combustion Properties of Water-Based Varnish, II. International Furniture Congress, 36-42, 13-15 October 2016, Muğla, TURKEY

8. Gao, M., Sun, C.Y., Wang, C.X. (2006). Thermal degradation of wood treated with flame retardants, Journal Of Thermal Analysis And Calorimetry, 85(3): 763-769.

9. Goldstein, I.S. (1973). Wood Deterioration and Its Prevention by Preservative Treatments: Chapter 9 Degradation and Protection of Wood From Thermal Attack, Syracuse University Press, 307-339, New York.

10. Ibach, R.E. (2013). Handbook of Wood Chemistry and Wood Composites, Chapter 5 Biological Properties of Wood, CRC Press, 5: 99-126, New York, A.B.D.

11. Jiang, J., Li, J., Gao, Q. (2015). Effect of flame retardant treatment on dimensional stability and thermal degradation of wood, Construction and Building Materials, 75: 74-81.

12. Jinxue, J., Jianzhang, L., Jing, H., Dongbin, F. (2010). Effect of nitrogen phosphorus flame retardants on thermal degradation of wood. Construction Building Materials, 24(12):2633-2637.

13. Keskin, H., Erturk, N.S., Colakoglu, M.H., Korkut, S. (2013). Combustion properties of Rowan wood impregnated with various chemical material, International Journal of Pysical Sciences, 8 (19) 1022-1028.

14. Kordina, K., Meyer-Ottens, C. (1977). Feuerwiderstandklassen von Bauteilen aus Holz und Holzwerkstoffen, In: Informationsdienst Holz, Dusseldorf, Germany.

15. Kurt, Ş., Uysal, B. (2009). Combustion Properties of Oak (Quercus robur L.) Laminated Veneer Lumbers Bonded With PVAc, PF Adhesives and Impregnated with Some Fire-Retardants, Composite Interfaces, 16(2-3), 175-190.

16. Lee, H.L., Chen, G.C., Rowell, R.M. (2004). Thermal properties of wood reacted with a phosphorus pentoxide-amine system, Journal of Applied Polymer Science, 91: 2465-2481.

17. LeVan, S.L., Winandy, J.E. (1990). Effects of Fire Retardant Treatments on Wood Strentgh: A Rewiew, Wood and Fiber Science, 22 (1):113-131. 
18. Özcan C (2011). Yeni bir yanma düzeneğinin hazırlanması ve 1sıl işlem görmüş ağaç malzemelerin yanma özelliklerinin belirlenmesi, Bartın Üniversitesi Doktora Tezi, Fen Bilimleri Enstitüsü, Orman Endüstri Mühendisliği Anabilim Dalı, Bartın, 127s.

19. Özcan, C., Esen, R., Likos, E., Kurt, Ş., Yapıcı, F. (2012). The Effects of Fire Retardants Paint on Combustion Properties of Fir Wood, Kastamonu University Journal of Forestry Faculty, 12(3), 124-126.

20. Özcan, C., Uysal, B., Kurt, Ş., Ertekin, S. (2013). Yangın Geciktirici Boya Uygulanmış Sapelli Ağaç Malzemelerin Yanma Özelliklerinin Belirlenmesi, II. Ulusal Mobilya Kongresi, 11-13 Nisan 2013, Denizli, Türkiye.

21. Özcan, C., Korkmaz, M., Esen, R., Kılınç, İ. (2018) Combustion Properties of the Fire-Reterdant Paint Coated Ash Wood, 14th International Combustion Symposium, 232-235, 25-27 April, Karabük, Turkey.

22. Ozdemir, F., Serin, Z.O., Tutuş, A. (2017). Investigation of the Effect of Some Fire Retardant Chemicals and Mineral Materials Used in Surface Coating on Combustion Performance of Particleboard, BioResources 12 (4), 8862-8869.

23. Rowell, R.M. (2012). Handbook of wood chemistry and wood composites, Chapter 6 Thermal Properties, Combustion and Fire, CRC Press, 2: 113-166, New York.

24. Russell, L.J., Marney, D.C.O., Humphrey, D.G., Hunt, A.C., Dowling, V.P., Cookson, L.J. (2004). Combining fire retardant and preservative systems for timber products in exposed applications state of the art review, Forest and Wood Products Research and Development Corporation,10-35, Melbourne.

25. Terzi E (2008). Amonyum Bileşikleri ile Emprenye Edilen Ağaç Malzemenin Yanma Özellikleri. Yüksek Lisans Tezi, İ̈̈ Fen Bilimleri Enstitüsü, Orman Endüstri Mühendisliği Anabilim Dalı, İstanbul, $126 \mathrm{s.}$

26. TS 2471 (1976). Odunda Fiziksel ve Mekaniksel Deneyler İçin Rutubet Miktarı tayini, Türk Standartları Enstitüsü, Ankara.

27. TS 2472 (1976). Odunda Fiziksel ve Mekaniksel Deneyler İçin Birim Hacim Ağırlı̆̆ın Tayini, Türk Standartları Enstitüsü, Ankara.

28. Üretici Firma-1 (2018). Hemel Empenye Sanayi ve Ticaret A.Ş., İstanbul, http://hemel.com.tr/content/media/document/TDS_Sayerlack_TA_TR.pdf

29. Üretici Firma-2 (2018). Ecelak Boya Kimya $\quad$ Ltd. Şti., İzmir, http://www.ecelak.com/files/ECELAK\%20ANT\%c4\%b0FLAM\%20S\%c4\%b0STEMLER.pdf

30. Yalınkılıç, M.K. (1993). Ağaç Malzemenin Yanma, Higroskopisite ve Boyutsal Stabilite Özelliklerinde Çeşitli Emprenye Maddelerinin Neden Olduğu Değişiklikler ve Bu Maddelerin Odundan Yıkanabilirlikleri, Doçentlik Tezi, KTÜ Orman Fakültesi, Trabzon, 312 s.

31. Yapıcı, F., Uysal, B., Kurt, Ş., Esen, R., Ozcan, C. (2011). Impacts of Impregnation Chemicals On Finishing Process and Combustion Properties of Oriental Beech (Fagus Orientalis L.) Wood, Bioresources 6(4) 3933-3943.

32. Yaşar, Ş.Ş., Atar, M. (2018). The Effects of Wood Preservatives on the Combustion Characteristics of Sessile Oak (Quercus Petreae L.), Politeknik Dergisi, 21(4), 805-811. 